\title{
COLOUR INHERITANCE AND SEX DETERMINATION IN LEBISTES
}

\author{
By $\varnothing$. WINGE and E. DITLEVSEN \\ Carlsberg Laboratory, Copenhagen, Valby
}

\section{GENERAL INTRODUCTION}

Received $16 . x i \cdot 46$

Авоuт 25 years have passed since the small, viviparous tropical teleostean fish, Lebistes reticulatus, was first employed for genetic studies.

Lebistes reticulatus (Peters) Regan, the "millions fish " or "guppy" is well known to all aquarium fanciers. It is characterised by a very
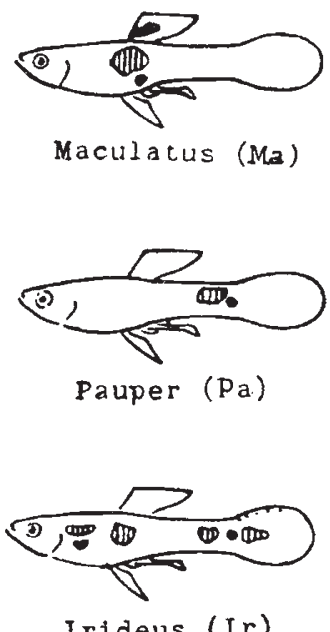

Irideus (Ir)

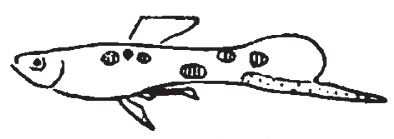

Armatus (Ar)

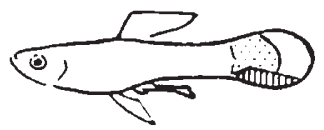

Coccineus (Co)

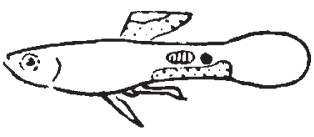

Vitelinus (Vi)

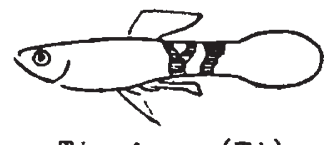

Tigrinus (Ti)

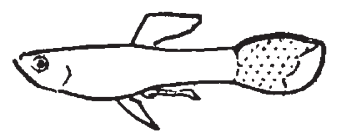

Luteus (Lu)

andm red $\because$ yellow

black grey

FIG. 1. - The effects of some colour genes in males of Lebistes reticulatus; at the left are seen some of the "absolutely Y-linked" genes; at the right some genes that may occur in $\mathrm{X}$ as well as in $\mathrm{Y}$.

conspicuous sex difference. The female is normally about $5 \mathrm{~cm}$. long, the male only about $3 \mathrm{~cm}$., and the difference is rather pronounced in other respects also. Thus the male is more slender, and its anal fin is transformed into a copulating organ. Further the colour of the female is generally a rather inconspicuous greyish-brown, whereas 
the male is provided with beautiful red, yellow and black spots and configurations on the body and often on the dorsal and caudal fins too ; the caudal fin may also be elongated.

The studies carried out on Lebistes concern the inheritance of the colour pattern and sex determination. Lebistes reticulatus has the male with $\mathrm{XY}$ and the female with $\mathrm{XX}$. It was the first organism in which a Y-linked inheritance was demonstrated (Schmidt, I920; Winge, I92I); two rather different colour patterns, $I r$ and $M a$, were found on crossing two strains continually to be transmitted from father to son, grandson and so on, and never to be inherited

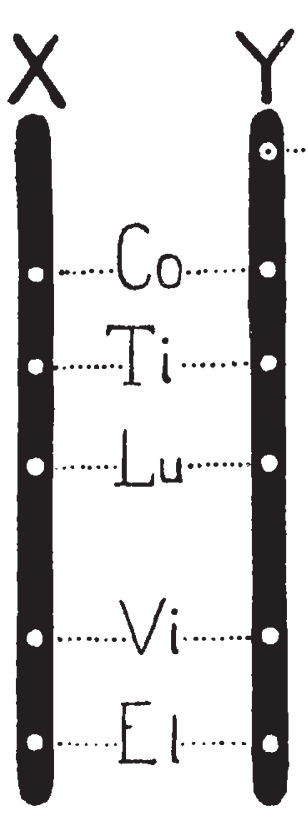

Frg. 2.- Map showing the position of some genes in $\mathrm{X}$ and $\mathrm{Y}$. through the mother. Subsequently by thorough genetic analysis more than 20 colour genes have been demonstrated (Winge, 1922, 1927 ; Blacher, 1927, 1928 ; Kirpichnikow, 1935). Most of them are X-linked or Y-linked (see fig. I). The genes are dominant in the male. The female normally presents no colour pattern, even though it possesses genes for colour homozygotically.

Crossing-over between $\mathrm{X}$ and $\mathrm{Y}$ has been demonstrated in several cases (Winge, 1923, 1927, 1934). It was found that some genes are always Y-linked, while others may occur in $\mathrm{X}$ as well as Y. The Y chromosome of the male Lebistes contains always one of the absolute Y-linked genes that are to be looked upon as allelomorphs, e.g. $\mathrm{Ma}, \mathrm{Ir}, \mathrm{Pa}$ or $\mathrm{Ar}$. Other genes-as for instance $\mathrm{Ti}, \mathrm{Lu}, \mathrm{Co}, \mathrm{Vi}, \mathrm{El}$-may occur in $\mathrm{X}$ as well as in Y. It has been possible to map the sex chromosomes (see fig. 2). The maximum crossover percentage was found to be only 10 . It is reasonable to assume that $\mathrm{X}$ and $\mathrm{Y}$ are mostly homologous, as exchange of genes may take place ; and the difference between them may hardly amount to much more than the one gene, $M a$, or its allelomorphs. Possibly the colour gene itself is identical with a superior male-determining gene ; possibly the genes are merely strongly linked. So far it has not been possible to demonstrate any morphological difference between the $\mathrm{X}$ and $\mathrm{Y}$ chromosomes. All the chromosome pairs-a total of 23-are very nearly of the same size.

Genes located in the autosomes are Zebrinus, concerning a special colour pattern of the male (Winge, 1927), Gold and Blond, concerning the ground colour of the entire body in both sexes (Haskins and Druzba, 1938; Goodrich, Josephson, Trinkaus and Slate, 1944), and some genes that have nothing to do with the colour pattern.

$\mathrm{X}$-linked and $\mathrm{Y}$-linked inheritance of colour genes and crossing-over between $\mathrm{X}$ and $\mathrm{Y}$ have been found also in some kindred fishes: 
Aplocheilus (Aida, I92I) and Platypoecilus maculatus (Bellamy, I928; Fraser and Gordon, 1928-29; and Gordon, 1927). The latter has female heterogamy in domesticated stocks whereas male heterogamy has recently been observed in wild populations (Gordon, 1947).

The sex determination and the localisation of the sex genes in Lebistes have been elucidated especially by studies on $\mathrm{XX}$ males and $\mathrm{XY}$ females which have now and then appeared in the material (Winge, 1932, 1934). Sex-determining genes of differing potency, some pulling in a female direction, others in a male, are found distributed over a majority of the autosomes. The Y chromosome contains a strong male-determining gene closely linked to, or perhaps identical with, the absolutely Y-linked colour gene. Probably the $\mathrm{X}$ chromosome has a corresponding female-determining gene.

Here it will be appropriate briefly to mention the appearance of $\mathrm{XX}$ males. As stated above, the female Lebistes is colourless even

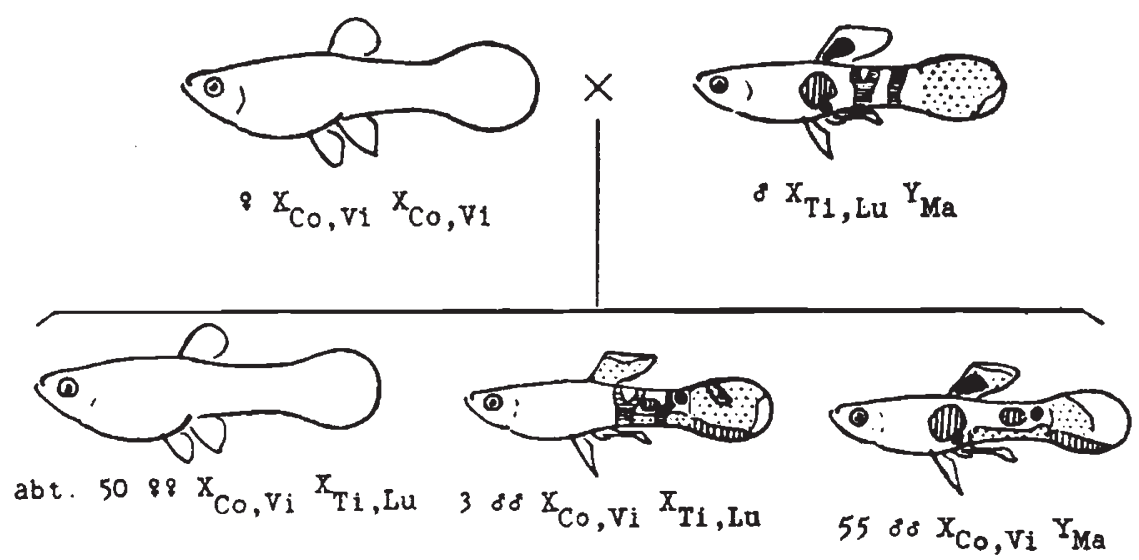

Fig. 3.-A cross between an $\mathrm{X}_{C o, V i} \mathbf{X}_{C o, V i}$ female and an $\mathbf{X}_{T i, L u} \mathbf{Y}_{M a}$ male, giving in addition to ordinary $\mathrm{XY}$ males three $\mathrm{X}_{C_{o}, V_{i}} \mathrm{X}_{T_{i}, L u}$ males

though she possesses genes for colour pattern. Within certain races, however, the female may sometimes show a trace of colour pattern, which might possibly be interpreted as evidence of a certain degree of masculinity. It must be pointed out, however, that as a rule the sexual differentiation in males and females is very clear-cut in Lebistes. Only exceptionally are hermaphroditic or intersexual individuals observed. In this respect there is a pronounced difference between Lebistes and, for instance, Lymantria. Crossing of two races, in which some of the females had a tendency to show colouring, gave-besides about 50 females and $55 \mathrm{XY}$ males-3 deviating males, who quite unquestionably had the formula XX (see fig. 3). Through inbreeding for several generations (back-crossing of the daughters to XX males) we finally obtained a race with about $5^{\circ}$ per cent. $\mathrm{XX}$ males and 50 per cent. XX females.

The origin of the $\mathrm{XX}$ males has to be explained as due to the accumulation of so many male-determining genes in the autosomes 
that the development could proceed in a male direction even in the absence of $\mathrm{Y}$. As the outcome is equal numbers of coloured $\mathrm{XX}$ males and uncoloured XX females, and as the inheritance of the X-linked genes is now no longer sex-linked but merely Mendelian, we may reasonably assume that now a pair of autosomes has become decisive in sex determination. The new sex balance was less firmly established than the normal. It was rather susceptible to external factors, so that in a cold and dark season there were rather considerable deviations from $5^{\circ}$ per cent. of either sex.

In another Lebistes family on one occasion XY females appeared. Crossing of a female of the formula $\mathrm{X}_{O} \mathrm{X}_{O}$ (i.e. with no colour genes in the $\mathrm{X}$ ) with a male of the formula $\mathrm{X}_{L i} \mathrm{Y}_{M a}$ gave-besides several ordinary $\mathrm{X}_{L i} \mathrm{X}_{O}$ females and $\mathrm{X}_{O} \mathrm{Y}_{M a}$ males-a few females with a

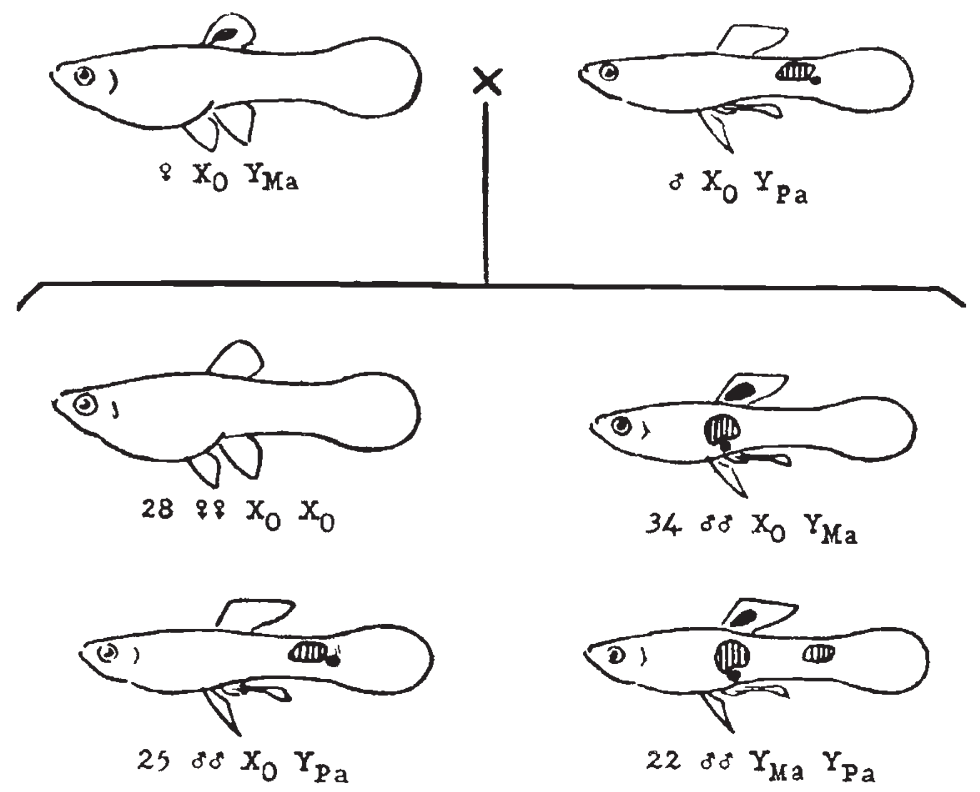

FIG. 4,-A cross between an XX female and an XX male.

spot on the dorsal fin which presumably was due to the $M a$ gene. By crossing such females with males containing another gene in the $\mathrm{Y}$ chromosome it could be shown that the females actually had the formula $\mathrm{X}_{O} \mathrm{Y}_{M a}$ (see fig. 4). This, as will be noticed, resulted among others in viable $\mathrm{Y}_{M a} \mathrm{Y}_{P a}$ individuals, which, on crossing with ordinary females, gave entirely male progeny.

The origin of $\mathrm{XY}$ females is explainable like that of $\mathrm{XX}$ males ; but here it is $\mathrm{XY}$ individuals which have accumulated so many female genes in the autosomes that, in spite of the presence of the strong sex-determining gene in $\mathrm{Y}$, the development has changed into a female direction. That YY individuals may be viable and fertile agrees very well indeed with the fact that the crossing-over experiments have shown the difference between $\mathrm{X}$ and $\mathrm{Y}$ to be slight. 
As emphasised in 1934 it should be possible by suitable inbreeding to obtain a change in the mechanism of sex determination which would result in a strain with XY females and YY males, and thus we should obtain a change from male heterogamy to female heterogamy. For this purpose the inbreeding was continued, and thus we made an interesting discovery. Even though the $\mathrm{Y}_{M_{a}} \mathrm{Y}_{P_{a}}$ males were fully viable and fertile the $\mathrm{Y}_{M a} \mathrm{Y}_{M a}$ type was lethal, which must be due to a recessive lethal gene in the $\mathrm{Y}$ chromosome, close to the $M a$ gene. Naturally this lethal gene contributes to maintain the normal sex determination within the $\mathrm{Y}_{M a}$ race (Winge and Ditlevsen, 1938).

The main points as to the distribution of the genes on $\mathrm{X}, \mathrm{Y}$ and autosomes in Lebistes and as to the manifestation of the genes as hitherto observed may be summarised as follows :-

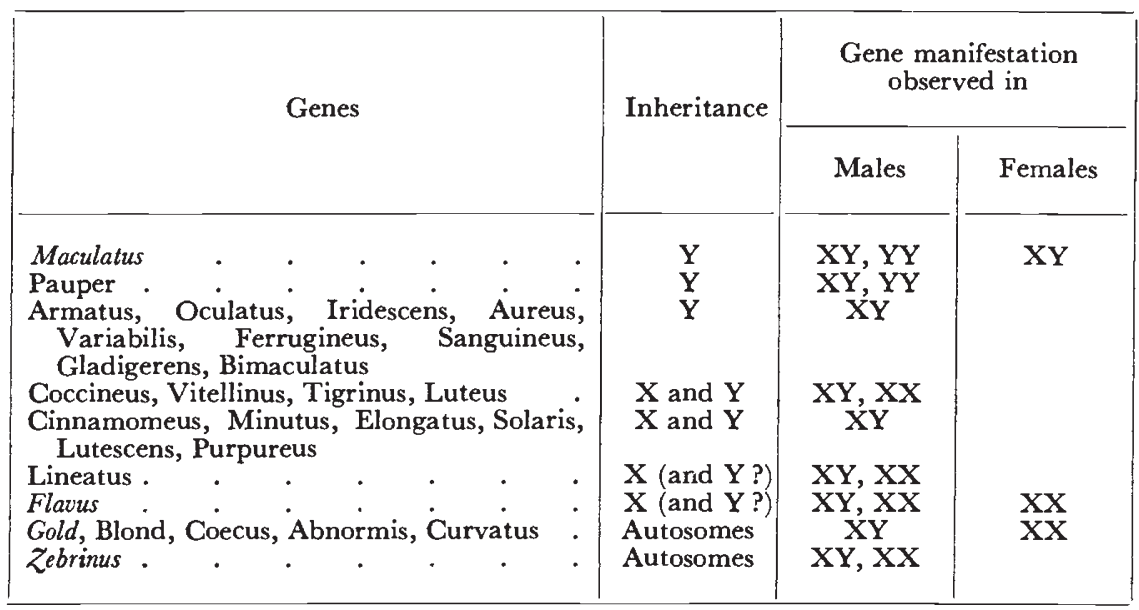

I. $\mathrm{Y}$ is never empty for colour genes. At least one colour gene is present ; while $\mathrm{X}$ and autosomes may be empty.

2. All genes are dominant in males, except the two autosomal recessives-Gold, Blond, and probably also the autosomal Coecus and Abnormis.

3. X-linked colour genes except Flavus never manifest themselves in females, not even when homozygotically present.

4. Old females may sometimes faintly show the colour genes which normally appear only in males.

5. YY males with two identical Y-chromosomes are probably always lethal. This, however, has so far only been demonstrated in $\mathrm{Y}_{M a} \mathrm{Y}_{M a}$.

In Aplocheilus latipes Aida has reported $\mathrm{XY}$ females as well as $\mathrm{XX}$ and YY males, but his explanation of the sex determination deviates somewhat from the one given here (Aida, 1936).

Goldschmidt (1937) has criticised our conception of the localisation of the sex genes, which he tries to bring into closer harmony with the prevailing view. Later on, in the section on sex determination, we shall deal with this criticism.

In 1944, for various reasons, it was decided to stop the Lebistes experiments in the Carlsberg Laboratory and dispose of the fishes. Lately we had been occupied, among other things, with a couple of genes which, in contrast to most of those hitherto studied, 
manifested themselves both in females and in males-Flavus and Gold. Now, after the war, we have received a paper by Goodrich, Josephson, Trinkaus and Slate (1944) that brings together many of the same facts we had found concerning the Gold Lebistes. Even though this section of our communication, therefore, on several points may appear as a repetition of the findings reported by Goodrich et al., we still thought that we ought to present it.

\section{THE " FLAVUS" GENE}

Some years ago Dr Anton Bruun of Copenhagen called our attention to a Lebistes strain, the femaile of which was characterised

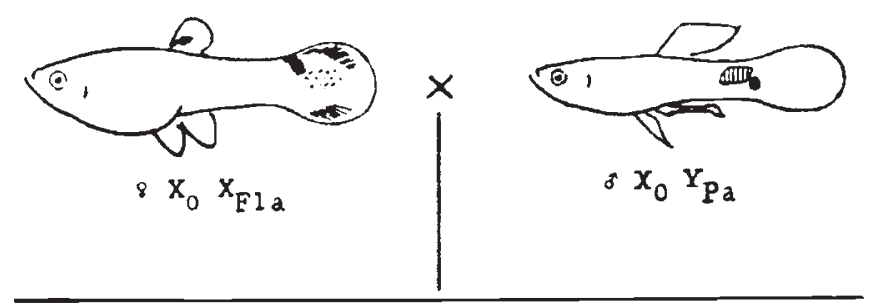

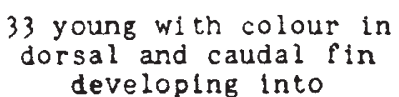
developing into
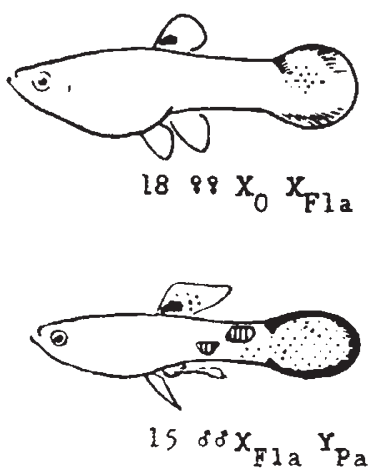

29 non-coloured young developing into
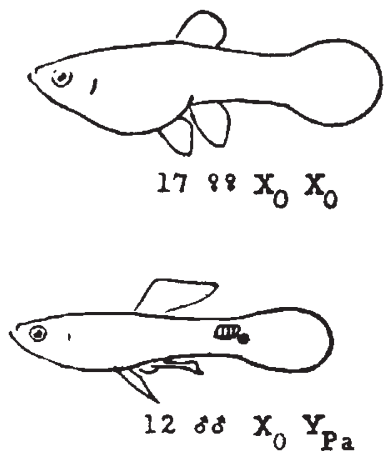

FIG. 5.-Cross between " coloured" female $\mathrm{X}_{O} \mathrm{X}_{F l a}$ and male of the Pauper race, $\mathrm{X}_{O} \mathrm{Y}_{P_{a}}$.

by the possession of colour in the dorsal fin and tail-fin. Mr Harry Andersen, printer, of Elsinore, was kind enough to give us some specimens of this strain.

In these "coloured" females the caudal fin, especially its middle part, is rather distinctly yellow with a blackish margin, while the dorsal fin presents a somewhat effaced black spot, often together with a little yellow (fig. 5). In the males of this strain ( $c f$. fig. 6) the caudal fin is very intensely yellow, bordered with black, and the dorsal fin is yellow with a black spot; a few red spots are seen on the sides of the body. This colour pattern, with the strong contrast between yellow and black, is one of the most decorative encountered in Lebistes.

In crossing experiments this pattern was found to involve a single 
$\mathrm{X}$-linked gene. This gene is dominant in both sexes, although it manifests itself less distinctly in the female. Further, it manifests itself earlier than the X-linked and Y-linked colour genes hitherto known. Even when the young are only about one month old they can be separated into "coloured" (with a dark spot in the dorsal fin, and somewhat black and yellow at the upper and lower margins of the caudal fin) and "uncoloured" (with colourless fins like normal Lebistes offspring). We designate the gene here concerned as Flavus (Fla).

The culture from which our fish originated was not "pure," therefore our first females were heterozygous, $\mathrm{X}_{O} \mathrm{X}_{\text {Fla }}$. Later on

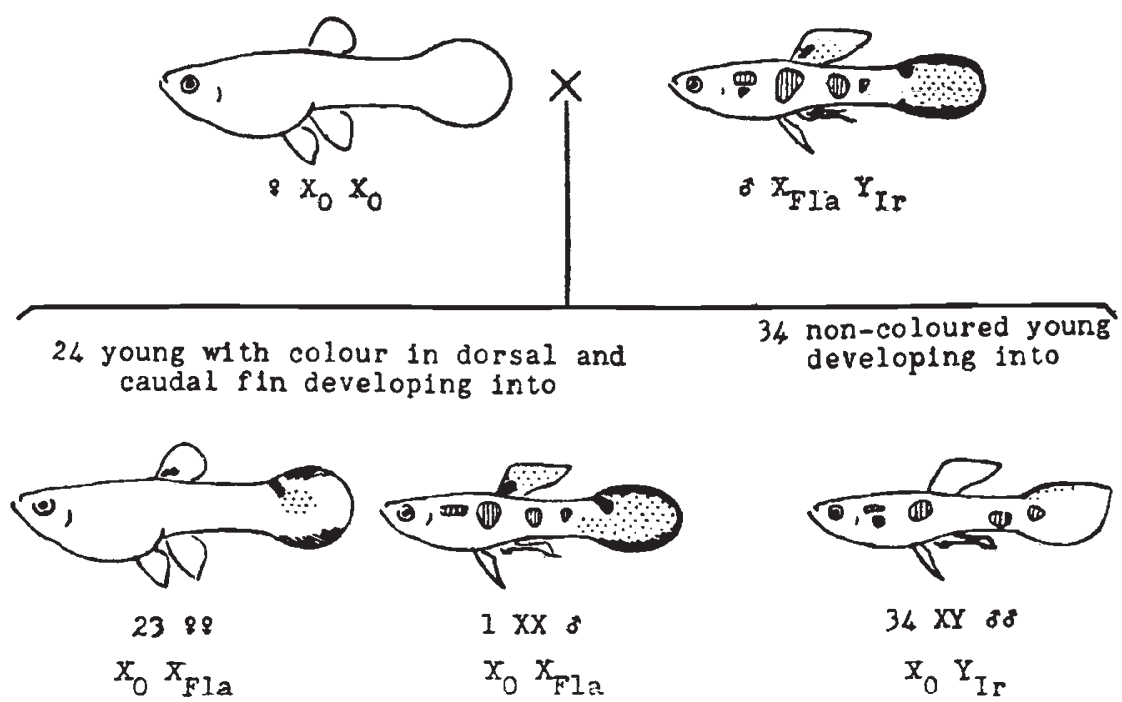

Fig. 6.-Cross of $\mathrm{X}_{O} \mathrm{X}_{O}$ female to $\mathrm{X}_{F l a} \mathrm{~T}_{I r}$ male showing $\mathrm{X}$-linked inheritance and segregation of an $\mathrm{X}_{O} \mathrm{X}_{\text {Fla }}$ male.

we succeeded in producing homozygous females, $\mathrm{X}_{F l a} \mathrm{X}_{F l a \text {, with an }}$ external resemblance to the heterozygotes.

Crossing of Fla 市 with $\mathrm{X}_{O} \mathrm{Y}_{M a} \approx\left(\mathrm{X}_{O} \mathrm{X}_{F l a} \times \mathrm{X}_{O} \mathrm{Y}_{M a}\right)$ (ㅇ $2345 \times$ đ 234 6)

gave :

$$
\overbrace{\text { IO } \text { 우 } 12 \text { ふึす }}^{\text {Non-Fla }}
$$

Crossing of Fla \& with $\mathrm{X}_{O} \mathrm{Y}_{P a} \sigma^{\star}\left(\mathrm{X}_{O} \mathrm{X}_{F l a} \times \mathrm{X}_{O} \mathrm{Y}_{P a}\right)$ see fig. 5, gave :

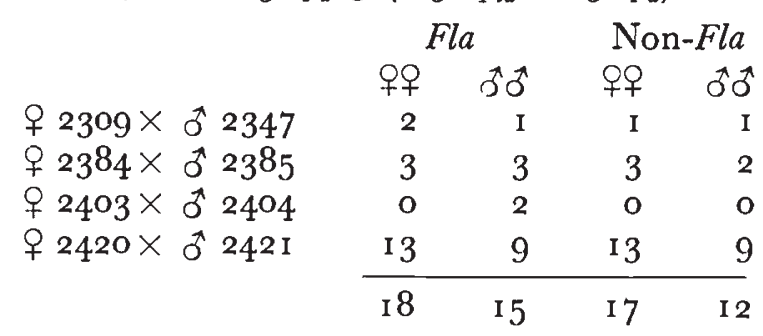


$\delta$ of the Fla strain crossed with $\mathrm{X}_{O} \mathrm{X}_{O}$ 우 $\left(\mathrm{X}_{O} \mathrm{X}_{O} \times \mathrm{X}_{F l a} \mathrm{Y}\right)($ ㅇ $2310 \times$ ๙ 2285), cf. fig. 6, gave :

$$
\overbrace{23 \text { 웅 I XX o }}^{\text {Fla }} \overbrace{\text { o } 99}^{\text {Non-Fla } 34 \sigma^{\star}}
$$

As is evident from the figure, the single Fla male did not differ from its father in appearance. It had not only the same yellow and black pattern in the caudal fin and dorsal fin, but also exactly the same red spots on the body. Subsequent experiments proved this son $\left({ }^{*} 2367\right)$ to be an XX male. The non-Fla sons show that, in addition to the X-linked Flavus gene, $\delta 2285$ possessed a Y-linked gene that seems identical with the gene Ir (Winge, I922, 1927). Other males, by the way, showed a Y-linked colour pattern somewhat different from this.

Crossing of non-Fla +, segregated from the Fla strain, with Fla $\precsim$ $\left(\mathrm{X}_{O} \mathrm{X}_{O} \times \mathrm{X}_{\text {Fla }} \mathrm{Y}\right)$ gave :

\begin{tabular}{|c|c|c|c|c|}
\hline & \multicolumn{2}{|c|}{ Fla } & \multicolumn{2}{|c|}{ Non-Fla } \\
\hline & qo & 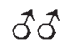 & 우우 & कే \\
\hline O $2322 \times$ ơ 2323 & $4 I$ & o & o & 49 \\
\hline q $2335 \times$ oี 2336 & 7 & 0 & 0 & 4 \\
\hline Q $2364 \times$ o 2365 & 7 & o & o & 4 \\
\hline & 55 & o & $\mathrm{o}$ & 57 \\
\hline
\end{tabular}

Crossing of Flavus mutually gave :

(a) Three matings in which the female evidently was heterozygous $\left(\mathrm{X}_{O} \mathrm{X}_{F l a} \times \mathrm{X}_{F l a} \mathrm{Y}\right)$ :

\begin{tabular}{|c|c|c|c|c|}
\hline \multirow[t]{2}{*}{ 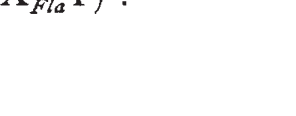 } & \multicolumn{2}{|c|}{ Fla } & \multicolumn{2}{|c|}{ Non-Fla } \\
\hline & 우우 & $\widehat{\partial \sigma}$ & Qq & ઢ઼ \\
\hline q $2333 \times ð ð 2334$ & 5 & I I & o & 8 \\
\hline 우 $2374 \times$ đ̋ 2375 & 7 & 5 & o & 9 \\
\hline 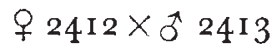 & I9 & 8 & 0 & 9 \\
\hline & $3^{I}$ & 24 & o & 26 \\
\hline
\end{tabular}

(b) Four matings in which the female was homozygous $\left(\mathrm{X}_{F l a} \mathrm{X}_{F l a} \times\right.$ $\left.\mathrm{X}_{\text {Fla }} \mathrm{Y}\right)$ :

\begin{tabular}{|c|c|c|c|c|}
\hline & \multicolumn{2}{|c|}{ Fla } & \multicolumn{2}{|c|}{ Non-Fla } \\
\hline & 우우 & $\widehat{\sigma} \sigma \hat{\sigma}$ & 우 & $\widehat{\sigma} \sigma^{*}$ \\
\hline 우 $2355 \times$ đ 2375 & I 5 & I3 & o & o \\
\hline q $2355 \times ð 2399$ & I & 0 & o & $\mathrm{o}$ \\
\hline Q $2457 \times 0^{\uparrow} 245^{8}$ & I 6 & 24 & o & o \\
\hline 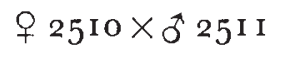 & 3 & 4 & o & $\mathrm{o}$ \\
\hline & 35 & $4 . \mathrm{I}$ & 0 & $\mathrm{o}$ \\
\hline
\end{tabular}


With the Flavus type we have an X chromosome characterised by a gene that is easy to recognise in the female as well as in the male. It seemed natural, therefore, to try to introduce this gene in a strain without a Y chromosome, where both females and males have two $\mathrm{X}$ chromosomes, in order to study its sexual effect.

As demonstrated previously (Winge, 1934), we have to assume that the $\mathrm{X}$ chromosome contains a sex-determining gene, pulling in a female direction. It seemed conceivable indeed that the new $\mathrm{X}$ chromosome would be of another potency than the $\mathrm{X}$ chromosomes already present in the $\mathrm{XX}$ race. Therefore numerous crossing experiments were made, partly of the aforementioned $\mathrm{XX}$ o 2367 and some other $\mathrm{X}_{F l a} \mathrm{X}$ males, obtained later, with females of the XX strain, partly of Fla females with XX males of our XX strain. In spite of extensive inbreeding it was not possible to attain 50 per cent. males, but several matings yielded a few XX males.

In the following counts the total formula of the $\mathrm{XX}$ females or males has not been given, as the exact formula for other colour genes was not known in all cases.

Crossing of Non-Fla $\mathrm{XX}$ females with $\mathrm{X}_{O} \mathrm{X}_{F l a}$ males gave :

\begin{tabular}{|c|c|c|c|c|}
\hline & \multicolumn{2}{|c|}{ Fla } & \multicolumn{2}{|c|}{ Non-Fla } \\
\hline & 우우 & के & 우우 & $\widehat{\partial \sigma}$ \\
\hline 우 $2366 \times \lesssim 2367$ & $3^{6}$ & $\mathrm{o}$ & 35 & $\mathrm{o}$ \\
\hline 우 $23^{8} 3 \times$ o $^{-1} 23^{67}$ & 14 & o & 15 & o \\
\hline ㅇ $2430 \times ð 2367$ & 28 & o & 23 & 0 \\
\hline 우 $2441 \times ð 2367$ & 7 & o & 6 & 0 \\
\hline ㅇ $245^{\circ} \times \sigma^{\star} 2367$ & 14 & $\mathrm{o}$ & I4 & I \\
\hline 우 $2463 \times ð 2367$ & 6 & $\mathbf{I}$ & 9 & 0 \\
\hline 우 $2469 \times{ }^{\star} 2367$ & 23 & o & 26 & o \\
\hline ㅇ $24^{8} 3 \times$ o 2367 & 8 & o & 6 & o \\
\hline 우 24 IO $\times ð ̋ 24$ I I & I9 & o & I 6 & o \\
\hline 오 $2429 \times ð$ 24I I & 28 & 2 & 23 & I \\
\hline 우 $2436 \times \sigma^{\pi} 24$ I I & 5 & o & 4 & o \\
\hline 우 $2443 \times \widehat{o} 24$ I I & 8 & $\mathrm{o}$ & 9 & o \\
\hline 우 $2459 \times$ đ 24 I I & 25 & I & 25 & $\mathbf{T}$ \\
\hline ㅇ $2464 \times \widehat{o} 24$ I I & 22 & 3 & 22 & 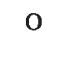 \\
\hline 우 $2487 \times 0^{\star} 24$ I I & I4 & $\mathrm{o}$ & I 2 & $\mathrm{o}$ \\
\hline 우 $2496 \times \delta^{\star} 2477$ & 9 & o & I 4 & o \\
\hline 우 $2503 \times$ ô2504 & $\mathbf{I}$ & $\mathrm{o}$ & $\mathbf{I}$ & o \\
\hline ㅇ $2507 \times ð ̋ 2508$ & I & I & 3 & 2 \\
\hline 우 $2506 \times ð 2367$ & 5 & 2 & 2 & $\mathrm{o}$ \\
\hline Total & 73 & IO & 265 & 5 \\
\hline
\end{tabular}


Fla females $\left(\mathrm{X}_{F_{F} a} \mathrm{X}_{O}\right)$ with Non-Fla $\mathrm{XX}$ ő $\sigma^{\star}$ gave :

\begin{tabular}{|c|c|c|c|c|}
\hline & \multicolumn{2}{|c|}{ Fla } & \multicolumn{2}{|c|}{ Non-Fla } \\
\hline & qq & $\widehat{0} 0 \hat{~}$ & 우우 & ఫేర \\
\hline 우 $2343 \times$ đૅ 2344 & 23 & o & I9 & 0 \\
\hline o $2431 \times 01243^{2}$ & 9 & o & I 2 & o \\
\hline q $2433 \times \delta 2452$ & $3^{2}$ & o & 33 & 0 \\
\hline † $2435 \times ð َ 235^{\mathrm{I}}$ & I I & o & 8 & 2 \\
\hline q $2442 \times$ क 2398 & 3 & o & 3 & \\
\hline ㅇ $2444 \times$ ठ 2398 & 8 & o & IO & \\
\hline Q $2447 \times{ }^{\star} 243^{8}$ & 4 & o & 4 & \\
\hline ㅇ $2453 \times$ ठ゚ 2454 & I 3 & 2 & I 4 & 3 \\
\hline Q $2455 \times$ ठै 2422 & IO & o & 6 & \\
\hline 우 $2474 \times$ ठ゚ 2475 & I 5 & o & I I & I \\
\hline 우 $2484 \times$ ơ 2485 & I 3 & o & I 2 & \\
\hline 우 $2488 \times$ 万 2489 & I I & o & I 3 & \\
\hline 우 $2497 \times$ ơ 2498 & o & 0 & $\mathrm{o}$ & \\
\hline 우 $2499 \times$ ठే 2500 & 3 & I & 4 & I \\
\hline 우 $2509 \times$ ơ 2486 & o & o & I & 0 \\
\hline 우 $2517 \times \sigma^{\star} 249^{8}$ & 5 & 0 & 3 & o \\
\hline Total & 160 & 3 & I 53 & \\
\hline
\end{tabular}

Thus among 877 individuals in all $26 \mathrm{XX}$ males were segregated out, namely i 3 with Fla and i 3 without.

Unfortunately the numbers for XX males are only small. But as Flavus and non-Flavus males appear in the same number the new $\mathrm{X}$ chromosome cannot in the potency of its sex-determining gene be so different from the genes already present as to influence sex determination.

\section{THE "GOLD" GENE}

The yellow Lebistes has been described by Haskins and Druzba (1938), and more thoroughly by Goodrich, Josephson, Trinkaus and Slate (1944). These authors found the yellow to be due to a recessive autosomal gene. In males as well as females of this race the whole body has a translucent yellow tone. This yellow Lebistes is designated as "fredlini" among fanciers. Goodrich et al. prefer to designate it as Gold, and they employ the symbols $G G=$ Wild Type, $g g=$ Gold. They have given a description of the effect of the gene on the chromatophores, chiefly the melanophores. In Wild Type the numerous melanophores form a "diamond-shaped pattern within the meshes of which are seen other somewhat more sparsely and irregularly 
distributed melanophores." The pattern results from the fact that the chromatophores follow the scales. In the Gold Lebistes the melanophores are far fewer in number, larger in size and limited more exclusively to the net pattern; the newborn Gold has no visible melanophores. Counting of the melanophores gave about half as many in Gold as in Wild Type. Goodrich et al. have also described two other recessive types with defective melanophores, which they designate as "Blond" $(b b G G)$ and the double-recessive "Cream" (bbgg).

In general our studies, which were carried out independently of these investigations, gave the same result. Our laboratory obtained its material, designated as "fredlini," from the Malmö Aquarian Society in Sweden through the courtesy of $\mathrm{Mr}$ Edvin Brorsson, teacher, Chairman of the Society.

The difference between the Gold strain and the normalcoloured is already conspicuous at birth, the normal being born with numerous melanophores on the body, while the Gold is entirely lacking in visible melanophores in the skin (see fig. 7). Gradually, as the Gold fish grow up, they get a certain number of melanophores on the upper part of the body. When by means of a knife a scale is removed cautiously from the back of an adult fish, a little of the epidermis will adhere to the posterior free part of the
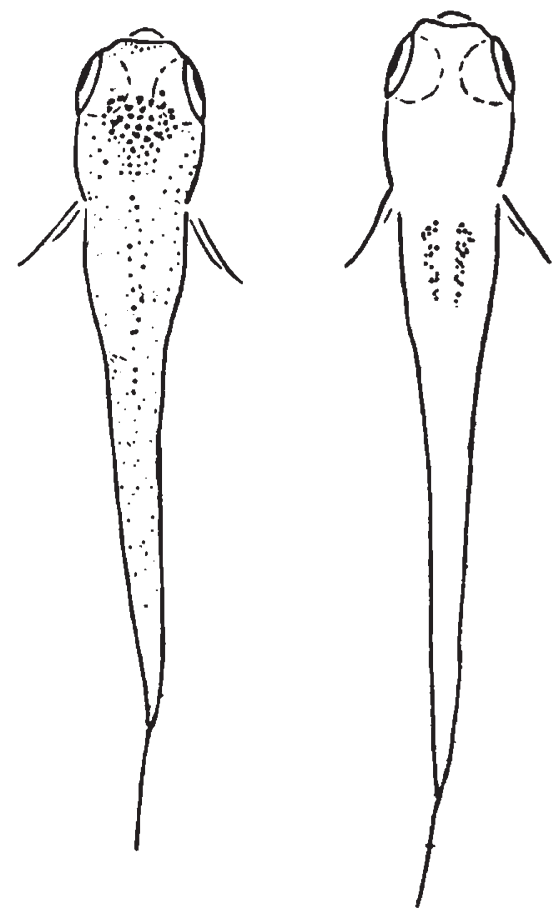

Fig. 7.-To the left, newborn normal (grey) young; to the right newborn Gold young - for illustration of the melanophores. The Gold young possesses no visible melanophores in the skin, but a few melanophores on the surface of the air bladder. (Enlarged.) scale, and under the microscope this gives a fairly distinct picture of the chromatophores--though not of those that are situated most deeply, as they are not removed by the detaching of the scale. Figs. 8 and 9 show scales of two females who measured 36 and $40 \mathrm{~mm}$. in length - a normal type and a Gold. The difference in the number of melanophores is very striking. The xanthophores are somewhat more numerous in the Gold fish than in the normal. Counting of melanophores and xanthophores on the scales was commenced but given up again, as it was found to be very 


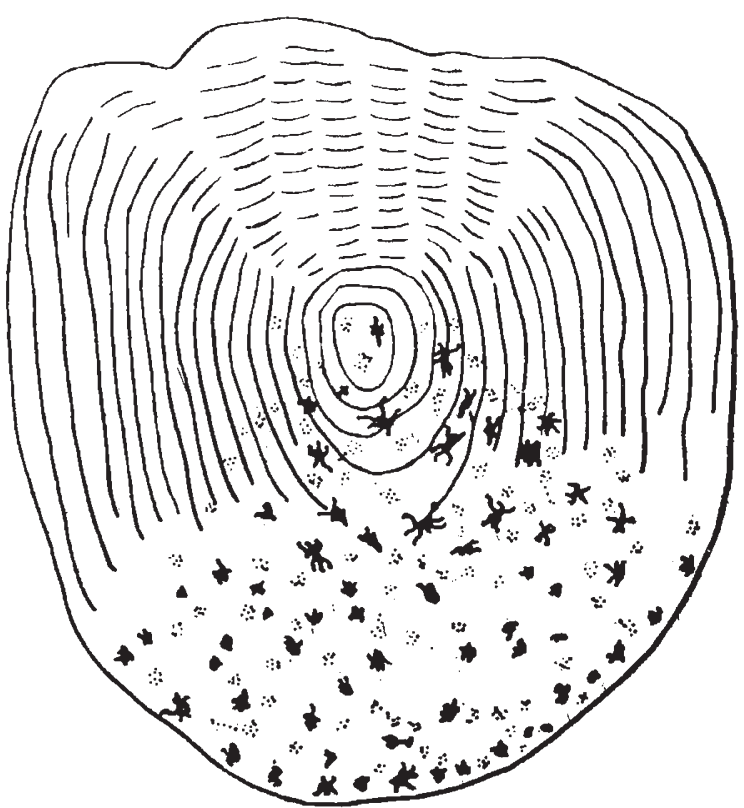

Fic. 8.-Scale of normal (grey) female (Wild Type) with the free posterior margin pointing downwards. Melanophores black, xanthophores dotted. (Greatly enlarged.)

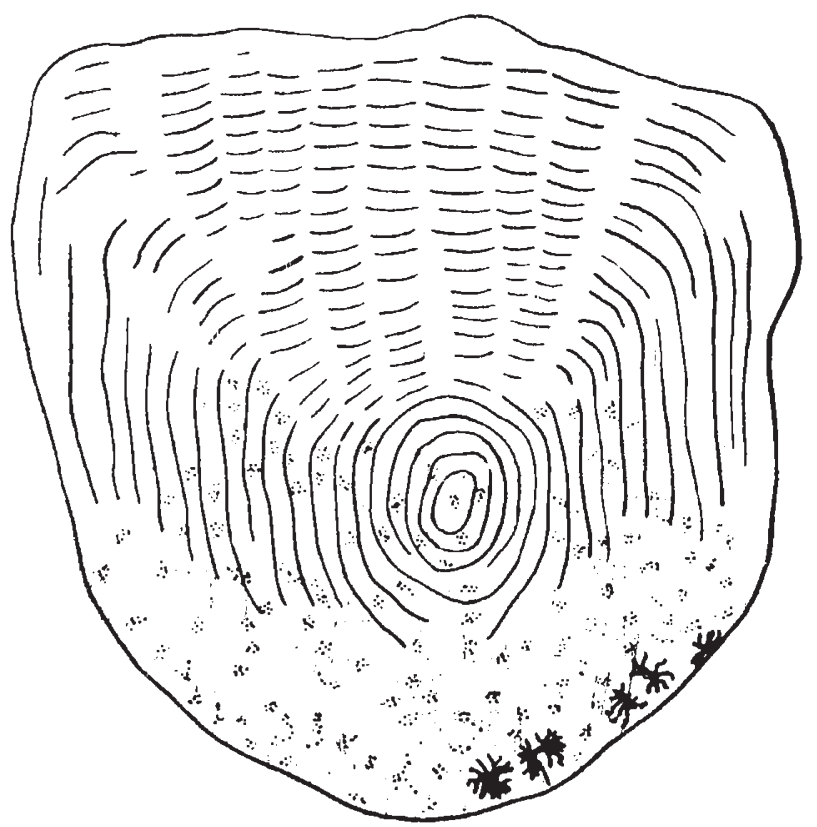

Fig. 9.-Scale of Gold female $(\mathrm{gg})$ with the posterior margin pointing downwards. Melanophores black, xanthophores dotted. (Greatly enlarged.) 
difficult to count the xanthophores quite accurately; a few exact counts are given in table $\mathrm{I}$.

TABLE I

Melanophore and xanthophore counts in Gold and normal females

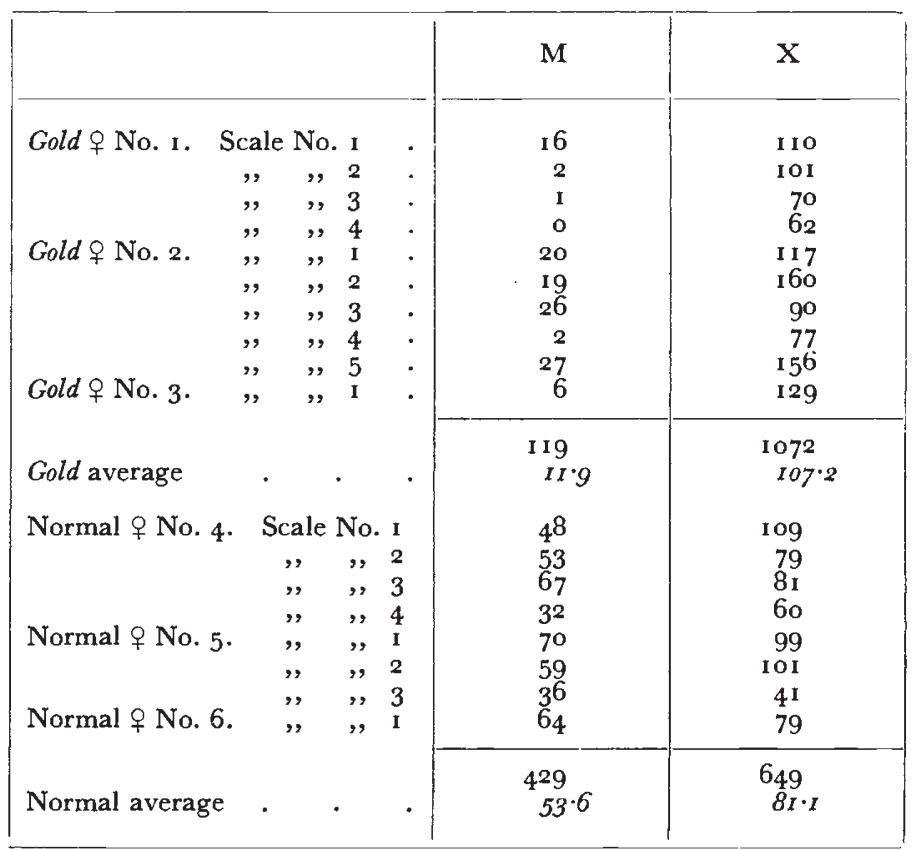

The outcome of our genetic experiments is quite in keeping with the findings reported by the authors cited above-that Gold is due to a recessive autosomal gene. Crossing of Gold with normal (= Wild Type) gives exclusively normal in $F_{1}$.

Crossing of $\mathrm{F}_{1}$ individuals mutually gives 3 normal : I Gold.

(a) $F_{1}$ of normal $q \times$ Gold ot crossed together ( $92098 \times{ }^{*} 2099$ ) gave

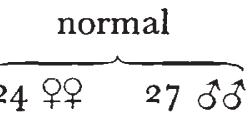

$$
\overbrace{\text { I3 우 }}^{\text {Gold }} \underbrace{01}_{700}
$$

(b) $\mathrm{F}_{1}$ of Gold $q \times$ normal ot crossed together ( $q 2303 \times \delta^{2} 2304$ ) gave
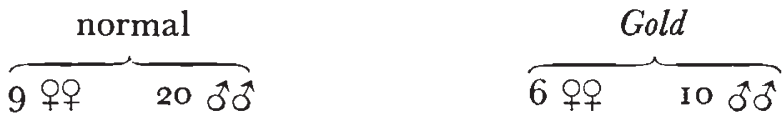

When to this we add some young ones that were not countered for sex, besides the outcome of a cross in which the male was XX, we have altogether :

$\begin{array}{lll}\text { (Total, 2 7 7) } & \text { I64 normal } & 53 \text { Gold } \\ \text { (Theoretically : } & \text { I } 63, & 54, \text { ). }\end{array}$


Nor is the Zebrinus pattern quite typical in the Gold males even though it can be made out here.

\section{THE "MACUlatus" GeNE}

In all the numerous crossing experiments carried out by us with the Maculatus gene, it has always appeared as a unit. In 1927 some selection experiments were reported with this gene, in which males with a particularly insignificant black spot on the dorsal fin were selected through several generations, and in this way some $\mathrm{X}_{O} \mathrm{Y}_{M a}$ males were obtained in which the black spot was altogether absent. Still, one and the same male was able with one female to give spotless sons, with another female, spotted sons. So this phenomenon was undoubtedly ascribable to the interaction of minor factors affecting the spots, not to any change in the Maculatus gene itself. In Gold males with $M a$ a distinct spot on the dorsal fin is most often absent, but this indeed is due to the defective development of melanophores in general, and the spot reappears on crossing with normal. In 1933, however, an instance of a truly hereditary alteration of the Ma gene was recorded.

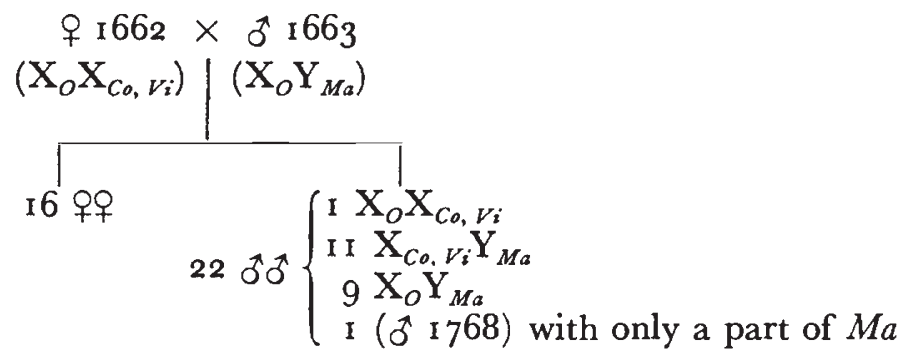

o 1768 (see fig. Io) had a red spot on the side, but no trace whatever of any spot on the dorsal fin. On crossing with $\mathrm{X}_{O} \mathrm{X}_{O}$
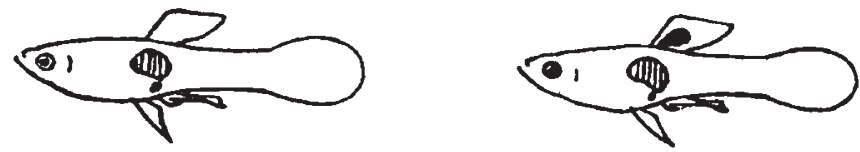

Fig. 10.- ${ }^{\pi} \mathrm{I} 768, \mathrm{X}_{O} \mathrm{Y}_{P_{a r t}}$ of $M a$ and brother with normal $M a$ pattern.

females he gave 8 daughters and I I sons, all of which quite resembled the father. Of the I I sons 2 were mated with $\mathrm{X}_{O} \mathrm{X}_{O}$ females and gave respectively 20 and 16 sons, all without any trace of a spot on the dorsal fin, just like $\delta$ I 768. A daughter of $\delta$ I 768 was crossed with a normal $\mathrm{X}_{O} \mathrm{Y}_{M a}$ oै and gave $\mathrm{I} 7$ sons, which all showed a normal Maculatus pattern with a well-defined black spot on the dorsal fin.

In order to preserve the altered Maculatus conveniently, some daughters and sons of $\delta$ I 768 were placed together in a tank, so 
that they would be able to maintain themselves by inbreeding. This strain kept constant from I935 to August 194I, when 6 males were drawn; they all presented the same appearance as 0 I 768 . There can be no doubt that here we are dealing with a true hereditary alteration of the Maculatus gene. Unfortunately, indeed, it cannot be decided whether this represents a mutation or a cross-over.

Blacher (1928) regards $M a$ as composed of at least two genes, one producing the black spot in the dorsal fin and the other producing the red side-spot on the body. The correctness of this interpretation has not, however, been demonstrated by him through cross-over or other experiments but only through the observation of few individuals with deviating colour pattern. Such variants, of course, do not allow us to draw any conclusions as to the existence of a gene or a gene complex.

\section{SEX DETERMINATION}

A thorough account of the sex determination has been given in a previous paper (Winge, 1934). As pointed out at that time, we have to assume that sex-determining genes-some pulling in a female direction, others in male-are distributed over a great many of the autosomes, with superior sex genes in the $\mathrm{X}$ and $\mathrm{Y}$ chromosomes. Accordingly the XY females would be individuals that contain a lot of autosomal sex genes pulling so strongly in the female direction that, in spite of the presence of the $\mathrm{Y}$ chromosome, the development has yet been female. Conversely, the XX males would have a lot of autosomal sex genes pulling sufficiently in the male direction.

Goldschmidt (1937) has criticised our theory and tried to make the experimental data comply with the older conception of sex determination, employing the old familiar formulas, MMFF in the female and MMF in the male, where $F$ is stronger than $M$ but weaker than MM. The appearance of the XX male would then be due to the circumstance that (either by presence in the stock, or by mutation, or by appropriate crosses as in Lymantria) there was introduced either a weak $\mathrm{F}$ or a strong $\mathrm{M}$. In his detailed account, Goldschmidt employs the formula $\mathrm{MMF}_{w} \mathrm{~F}_{w}$ for the $\mathrm{XX}$ male, in which, however, $\mathbf{M}$ is assumed to be constant and hence is left out. He then gets :

I. Accidental female with XX male :

$$
\mathrm{FF} \times \mathrm{F}_{w} \mathrm{~F}_{w}=\text { all the young } \mathrm{FF}_{w}=\text { qo } .
$$

2. Back-crossing :

$\mathrm{FF}_{w} \times \mathrm{F}_{w} \mathrm{~F}_{w}=\mathrm{FF}_{w}$ and $\mathrm{F}_{w} \mathrm{~F}_{w}=50$ per cent. $+\circ$ and 50 per cent. $\mathrm{XX} \precsim ð$.

Here, however, two facts must be remembered. Firstly, it was not at all the first back-cross that yielded 50 per cent. XX males; after the second back-cross only I XX male turned up among 3 I individuals and only the third back-cross resulted in $5^{\circ}$ per cent. of either sex. Secondly, we found no sex heterozygosity with regard 
to the $\mathrm{X}$ chromosome. It had just been demonstrated by experiment that in the $\mathrm{XX}$ race the inheritance of the colour genes associated with the $\mathrm{X}$ chromosome is not sex-linked. In the $\mathrm{XX}$ race the $\mathrm{X}$ 's are to be regarded as autosomes ( $c f$. Winge, 1932). Goldschmidt tries to explain the $\mathrm{XY}$ females correspondingly, wishing to parallel both cases to Lymantria. It was therefore of interest to see what might be the result of crossing an XY female with an $\mathrm{XX}$ male.

A female of the formula $\mathrm{X}_{O} \mathrm{Y}_{M a}$ (우 I80I) was crossed with a male of the formula $\mathrm{X}_{L i} \mathrm{X}_{L i}$ ( ${ }^{\star} \mathrm{I}_{\mathrm{I}} 793$ ), and two of their sons were crossed with females of the $\mathrm{XX}$ strain. In addition a son and a daughter of ㅇ I $801 \times 0^{*}$ I 793 were crossed together. Slightly schematised this experiment looks as follows :-

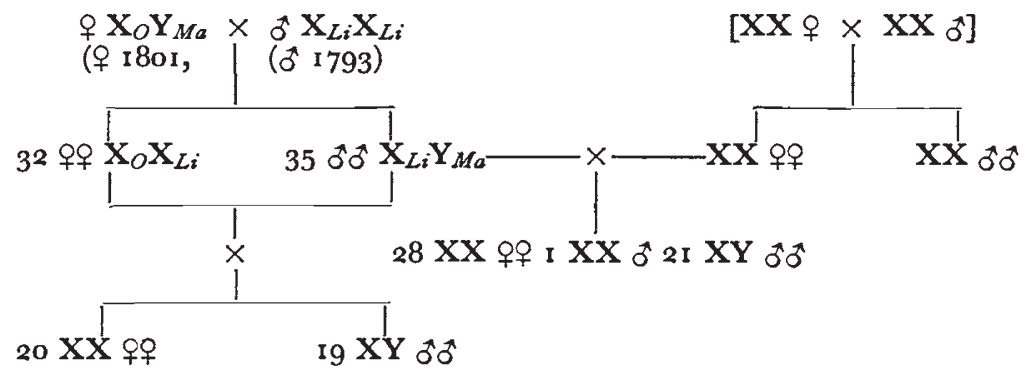

When in this pedigree the detailed formulas have not been given it is because several genes $(C o, V i, T i, L u)$ were introduced from the $\mathrm{XX}$ race, which gave a rather complicated segregation including crossing-over. The main point is that the $\mathrm{Y}$ chromosome was marked with $M a$, so that $\mathrm{XX}$ and $\mathrm{XY}$ individuals could easily be distinguished.

The present results agree fully with the assumption of multiple sex genes in the autosomes and particularly strong sex-determining genes in $\mathrm{X}$ and $\mathrm{Y}$. On crossing an $\mathrm{XY}$ female, possessing a particularly strong female autosomal set of genes, with an XX male which has a particularly strong male autosomal set of genes we get an $F_{1}$ with marked heterozygosity. The strongly female autosomes from the mother meet with a set of strongly male autosomes from the father, and these two sets balance each other so that the sex determination now depending on the $\mathrm{X}$ and $\mathrm{Y}$ chromosomes becomes normal both in the sons and in the daughters.

It was to be expected that the sex determination would be normal also in $F_{2}$, at any rate as long as the number of individuals was not very great; it is not surprising that a single $\mathrm{XX}$ male may segregate out when an $F_{1}$ male is mated to a female with strongly male autosomes.

On the other hand, if we were to explain the abnormal sex types by assuming variation in the strength of a single gene we would undoubtedly have to expect a segregation of $\mathrm{XY}$ females and $\mathrm{XX}$ 
males in $F_{2}$. If, as suggested by Goldschmidt in a private communication to the senior author in 1935 concerning the XX males, as in the case of Lymantria we were to introduce a plasmatic factor $\mathbf{M}$ and assume this to vary from one race to another and that a particularly weak $\mathbf{M}$ was present in the $\mathrm{XY}$ female, we would have to expect that in the inbred $F_{2}$ one-half of the XY individuals would be females ; and on crossing an $F_{1}$ male with a female of the strongly male race we would have to expect one-half of the $\mathrm{XX}$ individuals to be males. But it does not turn out this way.

So we will have to maintain that the view of the sex determination advanced by us (Winge, I934) is correct. The Y chromosome contains a strong male-determining gene, while the $\mathrm{X}$ chromosomes contain a female-determining gene, and sex-determining genes of varying potency are furthermore distributed over the autosomes in such a way that the sex determination normally depends on $\mathrm{X}$ and $\mathrm{Y}$. XX males appear when, through recombination including crossingover, particularly strong male-determining genes have accumulated in the autosomes; and XY females appear when sufficiently strong female-determining genes have accumulated in an XY individual.

It will be appropriate here to recall that a quite similar distribution of the sex-determining elements has been found in Melandrium (Winge, I93 I). In this plant, furthermore, the study of polyploid forms has shown that the $\mathrm{Y}$ chromosomes contain strong male-determining genes (Warmke and Blakeslee, I939; Westergaard, 1940). According to Westergaard, in Melandrium the sex is determined by " a very strong male-determining element in $\mathrm{Y}$ and a female-determining element distributed in the $\mathrm{X}$ chromosome and in the autosomes. Moreover, at any rate, some of the autosomes must contain male-determining genes." As will be noticed, this corresponds rather closely to the distribution of the sex genes in Lebistes.

\section{SUMMARY}

I. Two genes in Lebistes are shown to manifest themselves in both the male and the female :-

(i) Flavus, appearing as a black and yellow colour pattern in the dorsal fin and caudal fin, is localised in the $\mathrm{X}$ chromosome. It is dominant in both sexes.

(ii) Gold, already described by Haskins and Druzba and by Goodrich et al., characterised by a much smaller number of melanophores than in the normal Wild Type, is due to a recessive gene in an autosome pair other than the one that has formerly been shown to contain Zebrinus.

2. The Maculatus gene is shown to have undergone a change whereby the black spot on the dorsal fin completely disappears.

3. The outcome of a cross between the two abnormal sex types $\mathrm{XY}$ o and $\mathrm{XX}$ of agrees very well with the view previously advanced by the senior writer concerning the localisation of the sex genes. 


\section{REFERENCES}

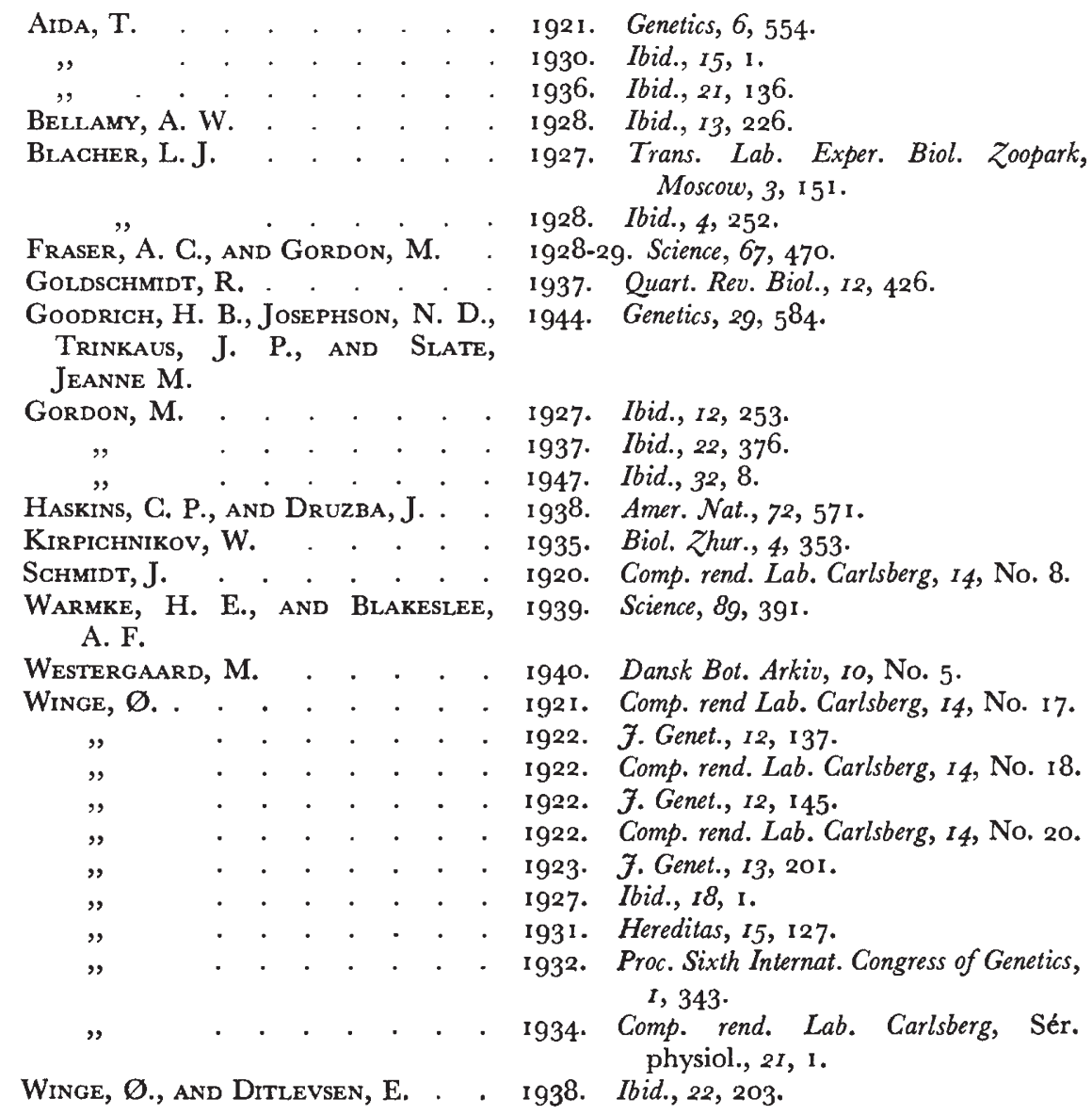

